\title{
A PLEA FOR A CANADIAN NATIONAL LIBRARY
}

$\mathrm{N}$

EARLY ten years ago the writer made a plea, through the University Magazine, for the establishment of a National Library in Canada. He pointed out that this country, with all its boasted educational facilities, lacks the keystone of a broad and efficient system of education. Under our constitution education is left to the Provinces, but nothing in the constitution prevents the creation of a National Library; - not a mere collection of books gathering dust upon the shelves, but a living force, functioning for the good of all the people. We are proud of our intellectual heritage from Great Britain and France, but we forget that our mother countries possess the greatest national libraries the world has ever seen. Every country in Europe, not merely the great nations, but the smaller ones as well, Switzerland, Holland, Belgium, Denmark, Greece, Norway, Sweden, Portugal and Finland, have built up national collections of books, administered in such a way that they have become real factors in the education of the people. Each of the South American republics possesses its Biblioteca Nacional. So does Mexico, and Cuba, and even the despised little Central American republics of Costa Rica and Honduras. Every other part of our own Empire has its national library, India, Australia, New Zealand, South Africa. Japan has a splendid collection, admirably organized and freely accessible to all the people. Canada stands alone among the nations-well, not quite alone, she ranks with Siam and Abyssinia. None of the three has a National Library.

The plea for a Canadian National Library aroused at the time a great deal of interest throughout the Dominion. It was taken up and supported editorially by practically every important newspaper in the country from Halifax to Victoria. Canadian writers and educationalists urged the immediate establishment of such an institution. The Royal Society of Canada adopted unanimously a resolution requesting the Dominion government to take action. So did the various Library Associations in Canada, and a number 
of historical, literary, and scientific societies. But, although the Prime Minister and several of his colleagues expressed their interest in the project, nothing was done. Other matters, more pressing from the point of view of a practical politician, constantly intervened. Perhaps antagonistic influences were quietly at work. In any event, the movement for a National Library, after gaining a good deal of momentum throughout the country, broke harmlessly at the capital. It has never been abandoned by those who had it at heart. At times, before the war, the prospects looked more or less favourable; but after 1914 it was definitely put aside, like a great many other important matters, until the world should emerge from its period of madness. To-day the people of Canada are grappling with the vital problem of reconstruction. And to-day one may very well ask them to consider if they can afford any longer to do without a national institution which, properly administered, might contribute in innumerable ways to the building up of the nation.

It may help to clarify the situation to describe very briefly what the smaller nations of Europe-those that compare roughly with Canada in population and wealth-have done in this direction. The National Library of Holland, the Koninklijke Bibliotheek at The Hague, contains considerably over half a million volumes, housed in a building admirably combining architectural dignity with the practical needs of such an institution. The library is open the year round to all students who may wish to. take advantage of its facilities; and books may not only be used in the building, but may be borrowed for use anywhere in the country. Residents of The Hague may keep books for a period of two weeks; students elsewhere in Holland are allowed a month.

The people of Switzerland, in their Stadt Bibliotheek at Berne, possess an equally well-organized and accessible National Library of a quarter of a million books. A resident in the most remote hamlet may send a request to the capital for any work he needs, and if it is available, he gets it by mail, without any troublesome: formalities, or any expense other than the actual postage. $\mathrm{He}$ may borrow as many as six volumes at a time.

What is said of the National Libraries of Holland and Switzer-land applies pretty generally to those of the three Scandinavian countries, and to the National Libraries at Athens, Lisbon and Brussels. The splendid Bibliothèque Royale at Brussels con-tained over six hundred thousand volumes before the war. It is not known just what the situation is to-day. 
The Library of Congress at Washington furnishes, however, the most helpful illustration of what may be accomplished by a National Library. At first sight it may appear to correspond to our own Library of Parliament, but in fact it is a radically different institution. The Library of Congress embraces three organizations in one: a Legislative Library, a National Library and a National Archives. It is a rare combination, one that only the genius of the present Librarian of Congress has made practicable, and one the ultimate wisdom of which he himself has questioned. In most countries these three institutions are quite distinct. 'We in Canada already have two of them, the Library of Parliament and the Dominion Archives. We still lack the third.

It has sometimes been suggested that the Library of Parliament is in effect a National Library. It is not, in any sense of the word. It is a Legislative Library, pure and simple. It was created to serve the needs of Parliament, not those of the public. None but Members of Parliament and Senators have any rights whatever within its walls. Its functions could unquestionably be enlarged, as have those of the Library of Congress, so as to make it in some sense at least a National Library; but not in the present building with its very limited space and with the present very inadequate staff. The advice of the Librarian of Congress, as the result of his own experience, is to keep the National and Legislative Libraries apart; and everyone who has really studied the question will agree that he is right. Let the Library of Parliament continue to fulfil the functions for which it was created; let the Dominion Archives continue its invaluable work in the collection and preservation of historical material; and let us have in addition to these a National Library.

To return to our illustration of the Library of Congress. What has been accomplished by and through this most efficient institution for the people of the United States can-allowing of course for differences of degree- be done by a Canadian National Library for the people of Canada. The Librarian of Congress recognizes that in any one country there should be a variety of libraries to meet the needs of different sections of the people. There are, to start with, the public libraries, themselves varying enormously in size and complexity according to the nature of the community they serve. Then there are university and school libraries, equally diverse in size, but not so much so in character. There are also kinds of special libraries, legal, medical, commercial, historical, scientific, municipal, legislative, etc. Beyond these 
again are what one may call the regional libraries-state libraries in the United States, and provincial libraries in Canada. And, finally, the National Library. Each of these attempts to meet the book needs of its own particular constituency, be it large or small, simple or complex. But all, except the last, are more or less limited in scope. Each excludes certain books, or certain classes of books, as unnecessary. Only one library may properly aim to be universal in scope, and that is the National Library. No National Library has ever contained, or ever will contain, all the books that have been published, but each may at least hope to bring together all the books that have been published in or about its own country and as much as possible of the literatures of other countries. Here, then, is one of the objects of a National Librarya last court of appeal for the man who needs a very rare, or very costly, or out-of-the-way book. There are more of these than most people imagine, and only the National Library can afford to collect them.

It is not enough that a National Library should contain the largest and most comprehensive collection of books in the country. It must also classify and catalogue them, provide bibliographies and other keys to its treasures. It must have upon its staff, or within reach, specialists capable of answering inquiries from all parts of the country as to what material exists on any particular subject, where it is, how it may be had, how most effectively it may be used. It must also, as far as practicable, carry its books to the people rather than force them to come to it. And in the broadest sense it must make itself a national centre of helpfulness to institutions and individuals from one end of the country to the other.

This is the sort of thing the Library of Congress has achieved across the line, and this is the sort of thing we can accomplish in Canada, if a sufficient number of Canadians will take the matter up and convince the government that they are in earnest.

LaWrence J. Burpee 